\title{
MAGE-3 Peptide (9-mer)
}

National Cancer Institute

\section{Source}

National Cancer Institute. MAGE-3 Peptide (9-mer). NCI Thesaurus. Code C29188.

A peptide derived from MAGE-3, a tumor-associated protein expressed by a variety of cancer cell types, including melanoma, breast, colon, lung, and thyroid. Dendritic cells harvested from a cancer patient may be exposed to or pulsed with the 9-mer MAGE-3 peptide (FLWGPRALV). Autologous vaccination with these altered dendritic cells may stimulate the host immune system to mount a cytotoxic $T$ lymphocyte $(C T L)$ response against tumor cells positive for MAGE-3, resulting in decreased tumor growth. (NCI04) 